\title{
CONSERVATION AND DEMOCRACY
}

\author{
BY A. B. WhEATLEY
}

Ontario Department of Lands and Forests

\begin{abstract}
The ugeful occupation of the total manpower of a nation is the first essential necessity for the general wellbeing of the whole, as well as for the individual. This condition is dependent upon an adequate use of all natural resources, particularly the renewable portion of those resources. Potential forest land comprises a very larme area in Southern Ontario in addition to the total area composed of farmers' woodlots. These factors indicate that there is opportunity to make conservation in its broadest aspect, forestry activities in particular, a full. time occupation for a large number of inadequately employed people.
\end{abstract}

$\mathrm{T}$

HE greatest potential national resource which any nation can possess is in its people. They are the means by which all things are put to useful or harmful purpose, depending upon the will of those people through their governments. In the broad sense of the term, a people are ruled by the kind of government they deserve and it is only through an enlightened public that progress can be made. Within our democratic form of rule, government action seems invariably to lag behind public opinion and it is when that lag becomes too apparent without corresponding legislative action, that a transfer of authority from one form of government policy gives place to another.

Every citizen of this country of military age or over has felt the effect, either directly or indirectly, of a national state of depression with its aftermath of large scale unemployment, and a state of almost unprecedented wartime prosperity now existing. True we have restrictions regarding the consumption of certain facilities and of certain commodities but, by and large, it is almost a foregone conclusion that, even within beleaguered Britain, the standard of nutrition and the availability of all essential requisites to a healthful existence are as high or higher than ever before.

One might make an exception as to housing conditions, but that situation has been brought about by external forces as a result of wartime destruction which no human exigencies could avoid.

The point in question simply resolves itself into the fact that the people as a national resource can and do conduct themselves in such a way that the product of the labour of most individuals is in alignment with a maximum productivity for the purpose of obtaining its goal, and in so doing the base standard of living has risen to meet the demands for sustaining the efforts required for total war.

With all of this effort on the part of the manpower resource there is probably as much as 50 per cent or more engaged directly in the business of the war or war effort, whose products are destined for destruction not only of themselves, as far as a peacetime use is concerned, but of the enemy. This involves likewise a colossal use for destruction of the manifold volume of our natural physical resources, of which the yield from forest land plays a very large part. 


\section{CONSERVATION AND DEMOCRACY - WHEATLEY}

The conservation and use of the manpower resource is the only way in which a living standard may be maintained or increased, and this must be in conjunction with the conservation and use of all our natural resources, particularly the renewable portion of those resources, on a sustained yield basis.

There can be little justification for waste or willful abuse of any basic commodity. There must be less justification for abuse of the source through which such commodities are made available. Since the abuse or waste of such source will tend to nullify and eventually destroy the possibility such renew. able resource possesses in its ability for supplying useful and essential things.

In Canada the effort involved in the continuance of much of our industry has to be of a seasonal nature. We have periods of feverish activity such as agriculture and water transportation, together with a host of lesser enterprises during the warmer weather seasons, and a considerable slacking off during colder seasons. This situation exists even during the present all out war effort, and although the number of men available for limited periods is much reduced, nevertheless where work is offered during this slack period, there seems to be a considerable number of men available. This situation certainly applied around each of the county forests in Eastern Ontario in the spring of 1942. It is, however, probable that the impoverished nature of agricultural enterprise around these areas is partly the cause of, and in turn is responsible for, an aftermath of less industrious individuals coincident with and partially responsible for a lack of individual enterprise. Tree planting activities thus offered a means of limited cash returns in the form of wages. This situation would apply more particularly to areas in which the land is largely sub-marginal.

The fullest use of manpower resource necessitates its use during slack periods, which in turn makes it imperative that opportunities be made available for useful occupations. Conservation activities, particularly Forestry enterprises, offer that outlet, and where such opportunities are lacking it means the irrevocable loss of potential accomplishment. One must not consider it as a cost or expense in the form of dollars and cents. The avoidance of enforced idleness is the first perquisite to progress and accomplishment.

The full-time constructive use of manpower should obviously be engaged in the production and distribution of things required to satisfy human needs. Work relief programs designed for expediency are largely an irreplaceable loss, an actual debit. Work programs designed to stabilize and rebuild our renewable resources must be an asset and an entry on the credit side of the ledger. As long as there is opportunity to increase the yield of such resources, i.e., the land, and to progress towards the ideal of sustained yield, there should never be a period of enforced idleness. One must even go further in this direction. Where there has been serious depletion in a natural resource, which in turn affects such things as soil stability, soil moisture, floods and drought, it becomes apparent that the extra effort must be taken from the usual processes of living in order to at least protect the productivity of such threatened resource.

The nation's resources belong to the people as a whole, no matter in whose name they happen to be registered. The present owners should be considered 
as tenants, with a life lease for the use of such resources. Such tenancy should imply that the productivity of the resource shall not be depleted on account of its occupancy. Where previous tenants have been responsible for its depletion, the present occupants should be assisted to bring; things right and to demand action. The people of a nation owe it to themselves and to posterity that any depletion in the productivity of a natural resource shall be remedied by the most direct action available. The use of all land must be put to the purpose for which it is best suited. All things considered, the welfare of the land, the greatest physical resource, which when destroyed is irreplaceable, should be given the most serious thought by all people.

There are today, in many sections of Ontario, men who are attempting to eke out an existence on land which is definitely sub-marginal in nature, land which is unfit for anything but timber production or for its water storage propensities. This type of land covers quite considerable areas and is at least partially included in that acreage known as waste land which in total is said to comprise some 8,000 square miles in Southern Ontario. Those farmers who are attempting to live on these areas are gradually becoming less and less effective as citizens and in many instances live in such a state of squalor and disrepute that they very often become social outcasts, and in general are an undesirable adjunct to our economy. It is indeed most likely that these individuals are potentially good citizens, but probably lack a certain effectiveness in some instances in that they seem incapable of improving their status by moving to more advantageous surroundings. By and large it is reasonable to state that sub-marginal land conditions is the prime factor in the cause of their present inertia, even though it can be reasonably argued that those of them who exhibited more initiative moved to better surroundings thus tend. ing to deplete the standard of effectiveness of those left behind.

Here then is another waste of manpower, a waste that is two-fold. First-the effective productiveness of these people attempting to farm submarginal land is so low that their total effort is required for their own consumption in order to live at all. It has been said that in all of Canada there are probably 50,000 farmers in this category. Second-a race of less desirable citizens is being generated which is very often the source of potential criminals and the breeding ground of illicit traffic of one kind and another.

There is a third loss from the conservationist's point of view in that the productivity of the land itself is not being utilized for its proper function, namely, wood production. Added to this is the loss entailed through the misuse of its function relating to the disposition of the annual precipitation.

The foregoing has dealt principally with manpower and its function as a national resource, and with certain losses of manpower entailed as a result of the use to which land is sometimes put.

Coincident with the manpower potential is his action in regard to the use of our physical natural resources of all kinds, but with special reference to land use policy.

The use of land has been the source of man's existence from the beginning. History reveals in many instances that man has developed civilization only to become destroyed by a vengeful nature as a result of refusing to conform to 
nature's demands as regards proper land use. One civilization has given rise to another in new found lands, or by the development of a civilization by a different branch of the human family. One reads of the wealth of the ancient city of Babylon which eventually destroyed itself through lust and greed. Its greatest asset today lies in the wealth of information archaeologists have revealed by digging into its buried ruins, buried by the sands of erosion, nature's punishment for those who were its cause, peopled only by small bands of roving nomads, with their camels or goats. It has been said that the goats, the only animal capable of existing under severe conditions of desolation, are responsible for the absolute waste conditions and the apparent inability of nature to rebuild a better vegetation. The goats eat the very roots of such vegetation as is present and eventually they themselves are forced to move. This may be the reason for the nomadic type of men that people such desert places.

It would appear then that there are two aspects to the problem of adequate land-use, and also that there is a certain interrelationship between them, although it may be said that this relationship is of more or less recent origin, and did not exist in the early days of land settlement and forest exploitation. It is also suggested that the adoption of an adequate land-use policy, the lack of which is mostly responsible for that ineffective portion of our people who inhabit such areas, would largely eradicate the main cause of the loss entailed. There are many people, even amongst those who are in more or less important and effective occupations, who would gradually retrogress under persistently adverse environmental circumstances. The depression years give ample proof of such an assertion. The eradication of conditions which create this adverse environment is in itself an obligation to a people interested in the wellbeing of all its citizens. The nation whose people are most effectively employed is the nation whose standard of living must be the highest under any given set of conditions.

It is a foregone conclusion that the present occupants, or owners, have neither the financial ability nor a knowledge of proper land-use to cope with the situation. Their total activities are taken up in the attempt to eke out an exisence, partly off an impoverished soil and partly at whatever outside employment is offered. Very often illicit means are taken to maintain their existence even at the merest subsistance level. No doubt the depressed condi. tion of Agriculture has had some effect on their low standard of living. This, however, is merely contributory, not the cause.

The reduction of so large an area of land, scattered throughout Southern Ontario, to the category described as waste or non-productive land (potential forest land) is due to an exploitation policy followed several generations back. It is not the direct responsibility of present or the immediate past occupants. The cause probably lies in the, until recent, belief of the inexhaustible nature of our land and timber resource, and the desire to secure large immediate returns both through the exploitation of the forest and a short-sighted agricultural enterprise.

The logical conclusion indicates that the present occupants have no alternar tive but to continue to use such land for purposes of immediate returns. The 
conservation needs, including reforestation and woodlut management, must be done by other agencies and, in view of pertinent facts, it must involve action to be taken by some national program involving government aid.

It is a national loss to permit conditions to exist whereby such sections of our population are, or will remain, non-productive and instrumental in the prevention of soil from producing its most suitable economic crop. This principle also applies to areas where the soil through its present or proposed use can not, or will not, sustain any permanent crop except wood.

This is of paramount importance to society as a whole. An unhealthy social problem exists where any portion of a population degenerates to the point where the self-respect of the people begins to lapse and where, as the natural consequence, the acceptance of relief, direct or iotherwise, becomes an expedient. There are few adults who, if provided with ample opportunity, will not become an asset to the community. This is particularly so if the educational means at our disposal were directed to their rehabilitation, and certainly the new generation could be so directed that their contribution to society would be of considerable value.

The factors which are instrumental in the development of self-respect are coincident with the feeling that the individual is engaged in a useful and important occupation. A feeling of pride in accomplishment is not possible where work is provided as a work relief measure usually at subsistence wage levels. Forest conservation, including reforestation, offer such occupational possibilities together with the phases of wildlife conservation and artificial works designed to control rapid runoff of water and soil erosion.

Rehabilitation includes the absolute necessity of making men feel that this job-conservation with all its implications-is vital to the wellbeing of the nation, and is not an expedient or short term policy purely designed to offer employment of a temporary nature in order to offset the ill effects resulting from a period of unemployment or lack of opportunity. Conservation in general, reforestation and woodland management in particular, should approach the category of full-time occupations. They should offer permanency of employment at adequate remuneration comparable to other enterprises requiring similar manpower ability.

Broadly speaking it should be possible to organize work of this kind in such a way that employment is made available within the vicinity of the domicile of those people requiring attention, and it is felt that such can be done at least during the initial years of the program of this essential work. Adjustment can doubtless be made with the accumulation of experience and the individuals thus employed will be in a much better position to seek employment elsewhere, if they so desire, following the betterment of local social environment.

It should be pointed out that reforestation of itself falls into the category of seasonal employment. The total duration of employment in this field cannot extend over a six weeks' period in the spring and in some localities another period of like duration in the fall-a maximum aggregate of twelve weeks out of the fifty-two. The period of employment directly affecting the planting may, of course, be extended to cover work to do with the preparation 
of land for the following year, such as the removal of undesirable tree specimens or species, and the laying out of roads and fire guards.

In order that the principle of permanency of occupation may pertain, other essential work must be carried out and it must be of such a diverse nature that winter as well as summer employment is available.

There are in Ontario considerable areas still in the form of natural wood. lots. In Eastern Ontario these comprise a total of close to 600,000 acres and as a matter of record it should be stated that the figures for the area of slash, swamp and waste makes the impressive total of 770,000 acres. The wooded land for the most part has been, and largely still is, lying in a state of utter neglect as to silvicultural treatment and management for maximum quantity and quality production of wood.

Here, then, is a self-made task crying out for action. The annual cubic foot increment of wood per acre is probably not over half of its potential maximum. The product both as to species and form is probably still worse in relation to its potentialities. The average woodlot should produce a much higher ratio of saw log material to cord wood than is being accomplished. It is highly probable that the increased yield from well managed woodlots, with a ready local market for all its products, would greatly increase the annual net return per acre.

These proposals suggest a radical or much advanced attitude towards the means by which an adequate land-use policy may be attained. The history of the development and exploitation of our country gives ample evidence that men as individuals, by and large, are not prepared to expend effort on projects representing long term investment from which they themselves will probably receive little or no monetary compensation. There are, of course, notable exceptions, but these can be counted on the fingers of one hand in comparison to the many thousands of land owners who are doing next to nothing or are, in fact, depleting the growing stock and slashing wooded areas. This is indicated by the alarming increase of slash and waste land acreage in Southern Ontario.

A leaf might well be taken from the book of experience available through the records of the forest and land use policy developed in Europe, particularly the Scandinavian countries. It has been argued here that Canadian people would not conform to rigid regulation as to the use to which land may be put and to the enforcement of a silvicultural policy in keeping with the needs of the forest. That is a debatable point. Certainly the means are available within a democratic country whereby the individual's actions are, or may be, regulated to comply with measures taken for the common good.

An unregulated land-use policy, and the ill effects of unrestricted deforestation are factors concerned with damaging soil erosion, destructive floods and drought, and pollution of springs and streams. These undesirable conditions do adversely affect the wholesome and healthful conditions essential to the wellbeing of a people.

The possible harm to society as a whole through its disregard of adequate land-use is not as spectacular or apparent as that involved in, say, unregulated 
milk production and distribution but it does directly affect the physical wellbeing of that portion of the people already suffering because of the bad effects of improper land-use. This in turn must have a direct bearing on the living standards of the whole.

A solution as to the financial responsibility of this problem may be found in the intelligent application of subsidies to those organizations or individuals with whom the responsibility for carrying out this work may be placed. It is important that the present owners of woodlands and waste lands associated with arable farm land should be encouraged to develop an appreciation and an understanding of the national benefits to be derived through a satisfactory land-use policy. Within areas embodying extensive waste-land conditions the extension of the facilities offered through the county forest medium to meet all forms of municipal possibilities could be developed. The possibilities as a source of long-term investment for Life Insurance companies and the like, could be thoroughly investigated.

The very nature of the forest or potential forest involves the principle of self-liquidating investments. By employing men otherwise unemployed or seasonally idle, and the use of land otherwise not productive, every cubic foot of wood produced, together with the other valuable benefits, must be a net gain to the material wealth of the people. Unless men are directed from other useful occupations in order to conduct the enterprise it must follow that the cost to the nation for such a project comes to absolutely zero except for wear and tear on whatever tools may be used.

It is a national loss to permit land of any kind to lie in idleness or to use it for purposes for which it is not suited.

The demand for the products of our forests for war purposes is immense. This demand cannot be met, largely on account of labour shortage. There is every likelihood that after cessation of hostilities the demand for these products will continue, at least for a few years, both here and abroad.

To what extent the immense area of forested land in Canada may be drawn on to meet this demand without risk of depletion is a problem in itself. Certainly a portion at least of that area still, or until recently, classed as inaccessible will be exploited. The point in question involves probable serious depletion of the most accessible of these forest resources, and this area is to a considerable extent made up of Southern Ontario woodlots. One must stop and consider the nature of the road upon which we are travelling, and to what end it will probably lead us.

The conservation of the natural resources upon which our industries depend must advance with the demands made upon those resources by industry. Are we to permit harmful, unregulated exploitation of our renewable natural resources in order to meet present demands as quickly as possible only to find that the productivity of such resources, due to excessive depletion, is insufficient to provide adequate production following this heavy demand? If this should happen any seeming present accomplishment in meeting present demand would be partly nullified due to the disastrous effects on the ability of our forest resources to continue to meet normal requirements. Truly we would then have killed the goose that laid the golden egg. 